\title{
Diderot e as mulheres, um debate do século XVIII
}

\author{
Vinicius de Figueiredo
}

Universidade Federal do Paraná / CNPq 

Na França, é a mulher quem dá o tom a toda reunião e sociedade. Ora, não se pode negar que, sem o belo sexo, as reuniões tornam-se insípidas e aborrecidas; se, porém, a dama dá o tom do belo, de igual modo deveria o homem dar o tom do nobre. Caso contrário, o convívio social se torna igualmente aborrecedor, embora por um motivo oposto, pois não há nada mais desprezível do que a doçura excessiva. De acordo com o gosto francês não se diz: "O Senhor está em casa?", mas: "A Madame está?", "Madame está no toilette", "Madame tem vapores"(uma forma de belo capricho); enfim, com Madame e de Madame se ocupam todas as conversações e todos os divertimentos. (Kant, 2002, A 88/89)

Este texto é uma nota que figura no início da IV Seção das Observações sobre o sentimento do belo e do sublime, publicadas por Kant em 1764. No Prefácio, Kant adverte que nela irá abandonar o "olhar do filósofo" para privilegiar o "olhar do observador". Pois bem, como considerar esta observação de Kant sobre as prerrogativas que o "belo sexo" exerce em solo francês, a ponto de determinar o tipo de sociabilidade, o estilo e a língua na França?

O trecho se encontra, como disse, no início da IV e última Seção, intitulada "Dos caracteres nacionais, na medida em que residem no sentimento diferenciado do belo e do sublime". Nas três Seções precedentes, Kant toma o belo e o sublime como as duas formas admitidas por um único sentimento, o sentimento refinado (feineres Gefühl), que ele cuida de diferenciar da satisfação ligada unicamente aos sentidos. Belo e sublime, cada qual a seu modo, são sentimentos que supõem o refinamento do espírito; correspondem, por assim dizer, ao estágio de uma sensibilidade cultivada, que se exprime nas mais diversificadas formas. De modo que, através da diferença entre belo e sublime, Kant classifica comportamentos, gêneros literários, relações entre homens e mulheres, etc. Na Seção IV, dedica-se a considerações sobre o espírito nacional de povos europeus e não europeus. É neste contexto que se inscreve nossa passagem: na França, diz o passo 
que puxa a nota, "a mulher é o objeto ao qual se referem mais assiduamente os méritos e as aptidões nacionais.” (Id., ibid., A 88).

Vejamos, então, o que isso significa. Se os franceses dão grande importância à mulher, é porque, assim como os italianos, inclinam-se pelo sentimento do belo. O francês, acrescenta Kant, "é cortês, atencioso e amável" (Id., ibid., A 87). Cortesia e amabilidade são características que Kant já havia ligado ao sentimento do belo nas seções precedentes. Por ora, interessa-nos reter que, na perspectiva de Kant, o caráter nacional francês assumiu a forma da efeminação da vida social. Kant, dotado de grande perspicácia e muito atento ao que se passava em seu tempo, faz aqui eco a uma impressão largamente difundida, na qual reflexões de ordem poética, antropológica e moral se combinam, nem sempre de modo linear, mas que apontam, todas, para o mesmo fenômeno: a França setecentista singulariza-se na Europa como nação em que as prerrogativas do feminino obtiveram um reconhecimento sem igual. Ora, como se formou este juízo de que a França é, essencialmente, "feminina"? Sem qualquer intuito exaustivo, gostaria de recolher alguns textos que contribuíram para esse juízo ao longo do século XVIII. Veremos que Diderot tem parte nisto, embora de forma surpreendente.

Em um ensaio publicado no The Spectator em 1 de setembro de 1711, Joseph Addison (1672-1719) tece considerações sobre a noção de gênio nas belas-letras. O "gênio", nos diz, arremata a admiração de todos e personifica os prodígios da humanidade. Sem o concurso das artes ou da instrução, o artista genial produz obras que não apenas tocam seus contemporâneos, como também atingem a admiração da posteridade. Addison, então, realiza uma comparação que evoca nosso tema:

Revela-se algo nobremente selvagem e extravagante neste grandioso gênio natural, que é infinitamente mais belo que todos os volteios e refina- 
mentos daquilo que os franceses chamam um Bel esprit, pelo que gostariam de expressar um gênio refinado pela conversação, reflexão e leitura de inúmeros autores polidos. O gênio que adentra as artes e as ciências toma delas uma espécie de tintura, e cai inevitavelmente na imitação (Addison, 1711).

A fim de classificar o oposto do gênio, Addison escolhe o Bel esprit valorizado pelos franceses. Enquanto o gênio é natural, nobre, selvagem e extravagante, o Bel esprit, de seu lado, foi refinado pela conversação, reflexão e leitura. Nada é menos aconselhável ao artista genial do que, ao invés de dar livre curso a sua espontaneidade, adotar o modelo francês. Fazê-lo, conclui Addison, é tomar a via da imitação, compreendida aqui de modo claramente negativo.

As considerações de Addison inscrevem-se em um momento significativo para a literatura e cultura britânicas, representado pela afirmação do valor da língua, poesia e dramaturgia nacionais diante dos padrões do classicismo francês, até ali considerado em toda a Europa modelo da língua culta. Posicionando-se contra a hegemonia francesa, Addison menciona Shakespeare no mesmo ensaio do The Spectator como exemplo nacional do "primeiro tipo de grande gênio" - um tipo infinitamente superior às expressões máximas da nação vizinha.

Como se sabe, esse debate sobre a natureza do gênio irá atravessar o século XVIII, repercutindo em obras decisivas para a estética em formação, como, por exemplo, as Conjecturas sobre a composição original (1759) de Edward Young, ou a Crítica do Juízo (1790), na qual Kant definirá o gênio como aquele que personifica uma regra ignorada por si mesmo. Nosso interesse aqui é mais pontual. Em que medida, ao articular categorias poéticas

1 "Our Countryman Shakespear was a remarkable Instance of this first kind of great Genius's” (Addison, 1711). 
com características nacionais, Addison não antecipa o juízo de Kant por onde começamos, conforme o qual na França quem dá as cartas é a mulher? Indagando de outro modo: podemos inferir com alguma segurança que "nobreza", "extravagância”, algo de "natural" e "selvagem" (as características do gênio, segundo Addison) se associam ao masculino, enquanto, de outro lado, o refinamento, a conversação e a polidez se associam ao feminino?

Embora Addison não explicite esse duplo alinhamento, ele contribui para a preparação do terreno sobre o qual irão frutificar articulações entre categorias poéticas, características nacionais e classificações de gênero, solo que Kant irá explorar em suas $\mathrm{Ob}$ servações, de 1764. Addison não é o único a preparar este terreno; mas talvez seja um dos primeiros. Graças a ele, um pouco mais tarde outros autores poderiam ir adiante e efetuar o vínculo entre França e efeminação.

É o que dá testemunho o "Discurso sobre a tragédia", redigido por Voltaire como introdução a seu Brutus, de 1731. Voltaire também exerceu o papel de tragideógrafo, como se sabe. Aí procurou levar adiante a tragédia em verso, que considerava tipicamente francesa e na qual Corneille, Racine e Despréaux, a seu ver, ainda não haviam sido superados. Mesmo assim, no "Discurso sobre a tragédia", Voltaire aponta os defeitos do teatro francês: "Possuímos na França tragédias estimadas que são mais conversações do que propriamente a representação de um acontecimento" (Voltaire, 1828, 2, t. I, p. 339). Em contraste com isso, peças que Voltaire avalia negativamente como "monstruosas", tais como as que se encenavam na Inglaterra,estariam, em seu juízo, repletas de cenas admiráveis, quase inexistentes no teatro francês. A delicadeza e o Bel esprit franceses, infere-se disso, passaram a operar como censura que limita a espontaneidade dos autores. Como Voltaire mesmo reconhece, em tom de censura ao público de seus versos: "Como ousaríamos representar em nossos teatros, por exemplo, a sombra de Pompeu, ou o gênio de Brutus, em meio 
a tantos jovens que tomam as coisas mais sérias somente como ocasião para dizer uma boa palavra?" (Id., ibid., p. 340)².

Todavia, há mais. Após admitir a grandeza de Shakespeare, embora desaprovando as "irregularidades bárbaras” de sua obra ("um homem que sequer sabia latim" [Id., ibid., p. 341]), Voltaire se detém sobre um tema que possibilitará reavermos bem de perto nosso fio condutor, a efeminação da cultura francesa setecentista. E o tema em questão é o amor. A última parte do "Discurso sobre a tragédia” discorre sobre ele, porque Brutus é uma tragédia que também fala do amor. E Voltaire se pergunta a si mesmo: "por que deveria eu misturar essa paixão com a virtude austera do senado romano e a política de um embaixador?" (Id., ibid., p. 349)3. Antes de responder, ele observa que é comum ouvir a reprovação de que a nação francesa "amoleceu o teatro por excesso de ternura”. O amor, porém, tem credenciais para figurar nos palcos, embora com cautela. "Querer o amor em todas as tragédias me parece um gosto efeminado; proscrevê-lo inteiramente é um mau humor desarrazoado". Interessa-nos a justificativa apresentada por Voltaire para essa conclusão:

Os gregos raramente encenaram essa paixão no teatro de Atenas; primeiro, porque suas tragédias, não versando senão sobre temas terríveis, acostumou o espírito do espectador a esse gênero de espetáculos; segundo, porque as mulheres levavam uma vida muito mais retirada do que as nossas, e que assim, a linguagem do amor não sendo, como é hoje, o tema de todas as conversações, os poetas estavam menos convidados a tratar dessa paixão, que de todas é a mais difícil de representar. (Id., ibid.)4.

2 E, um pouco adiante: "Mas, se os gregos e vós [os britânicos] ultrapassais os limites da decência, e se os Ingleses em especial produziram espetáculos horrorosos, querendo fazê-los terríveis, nós, Franceses, tão escrupulosos quanto vós fostes temerários, nos detemos em excesso, por medo de nos transportar; e por vezes, não atingimos o trágico, pelo receio de ultrapassar seus limites" (Id., ibid., p. 344).

3 Id., ibid., p. 349.

4 Note-se que essa observação conduz à disputa entre antigos e modernos: a mimesis moderna possui exigências próprias, a começar porque tem de representar uma pai- 
Eis-nos, assim, de volta a nossa questão, que assume uma formulação mais clara. Agora que as mulheres dispõem de um lugar social de destaque, o amor se tornou "o tema de todas as conversações". Se isso explica por que os críticos reprovam ao teatro francês ele ter-se "amolecido por excesso de afeição", é preciso, de um lado, evitar o excesso, sem, todavia, deixar de encenar o amor ${ }^{5}$. Omiti-lo seria romper a sintonia entre o autor e o público - um público que, especialmente na França, por conta do lugar social ocupado pelas mulheres, se efeminou.

A examinar mais de perto, essa constatação é o centro em torno do qual giram as considerações de Voltaire no "Discurso sobre a tragédia”. Aprofundando as intuições de Addison, tal constatação explica as diferenças apontadas por Voltaire entre o teatro inglês e o teatro francês. Delicadeza e Bel esprit compõem características nacionais francesas, em contraste com a genialidade inculta de Shakespeare. Resta a tarefa de evitar que a encenação do amor não redunde, como o próprio Voltaire reconhece acontecer o mais das vezes, em mera "galanteria" (op. cit., p. 350). Tudo se passa, portanto, como se, em sua tragédia, Voltaire tivesse de fazer frente ao desafio de reintroduzir "grandeza" e "assombro" em uma língua e uma cultura que se tornaram avessas à espontaneidade, devido à importância que nela ganhou a conversação, o galanteio, a delicadeza e a afeição. Entenda-se: devido às prerrogativas adquiridas pelas mulheres na França em vias de se tornar moderna - e isso a ponto de subsidiar as futuras observações de Kant sobre o caráter nacional francês como espírito voltado para agradá-las.

Munidos desses preliminares, passemos, então, à discussão de mais um texto, no qual a referência à efeminação da cultura francesa também está presente. De um lado, nosso fenômeno en-

xão que os antigos podiam ignorar. Poética e processo social encontram-se, portanto, conscientemente articulados no passo de Voltaire.

5 "Se por luxo vós entendeis o excesso, sabe-se que o excesso é pernicioso em todos os gêneros: na abstinência assim como na gulodice, na economia assim como em sua liberalidade" (Voltaire, 1964, p. 271). 
gendra uma crítica moral que corresponderá ao juízo de muitos europeus (franceses incluídos) sobre o que ocorreu na cultura francesa na primeira metade do século XVIII. De outro, esta que é uma avaliação negativa da efeminação apontará para uma alternativa positiva para se pensar a modernidade - uma alternativa, portanto, tributária da recusa das implicações morais identificadas na efeminação.

O texto a que me reporto é parte da crítica que Diderot lança à pintura rococó, em especial à poética de Antoine Watteau (1684-1721), considerado o precursor desse estilo, e que gozou de enorme prestígio na França da primeira metade do século XVIII. Trata-se de um trecho do Salão de 1765 , que transcrevo aqui:

Uma outra coisa que não choca menos são os pequenos hábitos dos povos civilizados. A polidez, essa qualidade tão amável, tão doce, tão estimável no mundo, é maçante nas artes da imitação. Uma mulher não pode dobrar os joelhos, um homem não pode estender seu braço, pôr o chapéu na cabeça e esticar um pé para trás, salvo sobre um anteparo. Sei muito bem que me objetarão com os quadros de Watteau: mas eu não faço caso disso e persisto. Tirai de Watteau suas paisagens, sua cor, a graça de suas figuras, de suas vestimentas; vede apenas a cena e julgai. É necessário às artes de imitação alguma coisa de selvagem, de bruto, de surpreendente e de enorme. (Diderot, 2000, p. 194).

O contexto no qual se inscreve esse passo é a discussão sobre a categoria de composição, central para a crítica de arte de Diderot. Da composição depende o ordenamento das figuras em um quadro, assim como a escolha de seu tema. Visto que Diderot concebe a pintura sob a égide da poesia (ut pictura poeisis), a destreza na composição é essencial ao pintor para que ele alcance o êxito narrativo, do qual depende o sucesso da pintura.

O que nos diz o passo citado? Que Watteau, por mais exímio que seja na utilização das cores, por maior que seja a graça de suas figuras, insiste em representar em suas telas "os pequenos hábitos 
dos povos civilizados". A essa pequenez, que, conforme Diderot, dá pouco a pensar, ele opõe o ideal que, a seu ver, deve pautar a escolha e o tratamento do tema pelo pintor: "É necessário às artes de imitação alguma coisa de selvagem, de bruto, de surpreendente e de enorme".

Numa coisa Diderot está certo: em sua pintura Watteau optou pelo "pequeno", não pelo "grandioso". O significado histórico de sua pintura residiu exatamente nisto: o de ter promovido a ruptura com a Grande Maneira e o Grande Gosto característicos do classicismo, do qual são expoentes pintores como Poussin e Le Brun (ver Ilustração 1). A partir de Watteau, a composição histórica, valorizada pela pintura clássica, viu-se negligenciada, dando ocasião a telas nas quais o que se vê é, de fato, "menor": não mais grandes feitos, realizados por grandes homens e representados em grandes telas, mas cenas de galanteio (ver Ilustração 2), retratos de festas campesinas, muita commedia dell'arte e, o que chamou a atenção do público, muitas mulheres ${ }^{6}$. Não que elas tivessem de esperar pelo rococó para ingressar na história da pintura; a novidade de Watteau estava no tratamento dispensado a aspectos ligados à representação do feminino, a começar pela ênfase sobre o divertimento e os jogos característicos do galanteio, da corte e da sedução que, através de Watteau, passam a ser visitados pela pintura. À primeira vista, a poética de Watteau adere totalmente à jovialidade da vida cotidiana de cortesões e burgueses, retratados em momentos de ócio, lassidão ou devaneio, envoltos em uma narrativa avessa a toda e qualquer teleologia.

Diderot também acerta ao comentar que essa opção de Watteau e de seus sucessores produziu implicações decisivas para a questão da composição. Se, na composição histórica valorizada

6 "Quase em tudo, a pintura decorativa possuía a tendência a ser menos solene, a preferir os temas do amor àqueles da glória” (Levey, 1989, p. 15). Eis-nos, assim, na ordem das questões em torno das quais gravitarão um pouso adiante as observações de Voltaire no prefácio a seu Brutus. 
pela doutrina clássica, a cena se ordena a partir de um centro visível - de modo a articular as ações das personagens em torno do foco representado pela ação heroica ou simplesmente segundo a hierarquia vigente entre elas ${ }^{7}$-, em várias composições de Watteau, se comparadas à pintura clássica, assiste-se a um rebaixamento narrativo: ele se contenta em apresentar cenas nas quais homens cortejam damas, soldados repousam no intervalo das guerras ou atores da commedia dell'arte figuram no palco ou fora dele, abandonados a sua existência momentânea e passageira. Duas concepções antagônicas da ação, duas atualizações irredutíveis da fortuna teatral nacional: enquanto Watteau aproxima-se de Marivaux (igualmente pouco compreendido pela crítica e amado pelo público ${ }^{8}$ ) através do recurso aos comediantes italianos, os pintores históricos contemporâneos a ambos permanecem ligados à tradição da tragédia francesa setecentista, cuja dicção elevada transportam para a pintura através do tratamento compositivo ordenado e hierárquico 9 .

Por que Diderot - e, com ele, a geração de 1750/6o - recusa tão peremptoriamente o partido tomado por Watteau e pelo roco-

7 Não deixa de causar espanto o fato de que paulatinamente a doutrina clássica tenha perdido sua eficácia prática, sem que, para isso, tenha sido preciso afrontá-la no plano teórico. A norma simplesmente caiu em desuso, de modo que, a partir de Watteau (ainda recebido na Academia como pintor histórico), a grande maioria dos pintores simplesmente ignorava, não o cânone, mas o lugar de honra aí reservado para a pintura histórica. Concomitantemente, a pintura de gênero, sem corresponder a uma categoria teórica definida, ganhava o público. De fato, são pouquíssimos os que, na primeira metade do século XVIII, buscam renovar a pintura histórica: seguramente Antoine e Charles Coypel e, em certa medida, Jean François de Troy e Carle Vanloo (cf. Chavanne, 2011).

8 Eis um exemplo: após recomendar a Marivaux "um estilo menos buscado e temas mais nobres", Voltaire contesta-lhe a tendência de "detalhar excessivamente as paixões e de perder de vista algumas vezes o caminho do coração, tomando vias excessivamente desviantes" (carta a Berger de 2 de fevereiro de 1736, in: Frantz \& Marchand, 2009, p. 202).

9 "Os artistas [ligados à pintura histórica] concentram suas composições sobre um momento-chave, que lhe faculta a evocar em uma única cena o conjunto do drama que se desenvolve sob os olhos do espectador. Eles não hesitam em inserir seus personagens em cenários que recordam o teatro e utilizam poses que fazem eco à gestualidade" (Chavanne, 2011, p. 10). 
có? E por que, ao fazê-lo, Diderot não adere ao cânone da pintura histórica tradicional mas, ao invés disso, aposta todas as suas fichas em uma renovação moral da pintura de gênero, que crê ser encabeçada por J.-B. Greuze?

A resposta à primeira pergunta reside na convicção de Diderot de que cabe à pintura narrar algo "grandioso". Isso nos recoloca na direção das questões de gênero, já que nos Ensaios sobre a pintura atua de forma implícita, mas não menos decisiva, a oposição entre o "feminino" e o "grandioso". Isso não significa, claro está, que Diderot reivindique que as mulheres sejam expulsas da pintura. Bastará expulsar o "feminino", tal como enaltecido pelo rococó e, atrelando-se a ele, pelas formas de sociabilidade que se propagaram da Regência em diante. Como se percebe, por trás das objeções de Diderot a Watteau e ao rococó figura a exigência de encontrar um correspondente da grandeza clássica em um contexto que se sabe não mais clássico, mas moderno. É, portanto, o desafio já identificado por Voltaire o que reaparece aqui, só que radicalizado pelo abandono de toda concessão à "futilidade" rococó. Como Diderot irá afirmar no salão de 1767 , é preciso "pintar o moderno à maneira antiga" (Diderot, 1996, p. 711) - ou seja, reapresentando sob novas vestes o grandioso. Diderot busca um equivalente, não um retorno à pintura clássica, o que requer elevar a pintura de gênero ao plano narrativo até ali exclusivo da pintura histórica. É o que faz Diderot, ao redefinir o princípio de classificação entre gênero e história na parte 5 - não por acaso, dedicada à composição - dos Ensaios sobre a pintura ${ }^{10}$.

Como se vê, tornar-se moderno, aos olhos de Diderot, não é abandonar-se a futilidades, como ele presumiu ter sido a esco-

10 "Eis o que é. A natureza diversificou os seres em frios, imóveis, não viventes, não sencientes, não pensantes, e em seres que vivem, sentem e pensam. A linha está traçada desde toda a eternidade: cumpria chamar pintores de gênero os imitadores da natureza bruta e morta; e pintores de história os imitadores da natureza sensível e vivente; e a querela estava acabada" (Diderot, 2000, p. 203). 
lha de Watteau e do rococón ${ }^{1 .}$ É antes superar a "pequenez", a "delicadeza excessiva", o "ornamental" e a "exterioridade" ligados ao feminino, para fazer jus às exigências morais e políticas do presente, ligadas que estão à ideia de liberdade e humanidade. Nessa medida, o primeiro desenho da noção de "autonomia", tão característica da inteligência europeia da segunda metade do século XVIII, é atravessado pelas questões poéticas - implicadas por questões de gênero - apontadas aqui.

A respeito disso, vale recordar em linhas gerais a forma sob a qual as mulheres são retratadas por Jean-Baptiste Greuze (17251805), a quem Diderot dirige elogios no Salão de 1765 . Greuze enfatiza o elemento patético, ligado ao sofrimento dos homens, enaltecido por Diderot (ver Ilustração 3). Embora o patético admita a representação de mulheres, elas são incorporadas à composição por razões bem diversas àquelas caras ao rococó. Nas telas de Greuze, as mulheres não personificam a efeminação da vida social - que, no rococó, se estendia aos homens, eles também voltados para as aparências, o gracejo e a melancolia personificados pelo comportamento feminino. Em Greuze, ao contrário, as mulheres comparecem, juntamente com os homens, como partes do grande drama da humanidade, que se torna sujeito da história. Greuze ressalta sentimentos e paixões ligadas ao sofrimento, ao abandono ou solidariedade filiais, moralizando os elementos cotidianos do trabalho e da vida doméstica. Destituído de leveza ou melancolia, o patético de Greuze enuncia o heroísmo dos fracos - ou, se não se quiser ir tão longe, o heroísmo daqueles que até ali haviam sido tradicionalmente representados sob o gênero cômico.

11 Não custa dizer que apenas exponho o ponto de vista de Diderot, carregado de implicações: segundo M. Levey, a concepção diderotiana de natureza conduziu a ver em Watteau artificialidade e frivolidade: "a redefinição do 'natural' levou a considerar a sensibilidade e a emoção de um Greuze como mais próximas da verdade” (Levey, 1989, p. 57). Em trabalho em curso, discuto mais profundamente os pressupostos da crítica de Diderot e sua pertinência em relação à poética de Watteau. 
Seguindo essa hipótese, dir-se-ia que Diderot pôde entrever nas cenas de sofrimento pintadas por Greuze o apelo à emancipação político-moral do gênero humano - o que, a seu ver, satisfazia à exigência de reaver o "grandioso" na pintura. Não mais, como no classicismo, o "grande feito" de um único indivíduo, mas uma grandiosidade em escala universal, agora representada pela história da humanidade em seu anseio por liberdade e justiça.A poética defendida por Diderot nos Ensaios de 1765, inteiramente anti-rococó, possibilita-nos vislumbrar retrospectivamente a solidariedade que irá unir a pintura moral de Greuze ao neoclassicismo de J.-L. David (1748-1825). Se, como diz Diderot, cabe à pintura "celebrar, eternizar as grandes e belas ações, honrar a virtude desventurada e arruinada, censurar o vício feliz e honrado, amedrontar os tiranos" (Diderot, 2000, p. 198), nesse caso a celebração do feminino - ao qual o rococó logo se viu reduzido - só poderá parecer um grande exercício de futilidade. A entrada em cena do gênero humano, retratado agora em sua grandeza, transcorre em direta oposição à valorização antecedente do gênero feminino, "pequeno" e superficial.

Iniciamos pela afirmação de Kant de que a França é a nação em que mais se destacam as prerrogativas da mulher e do feminino. Vimos que, bem antes disso, Addison sugeria que o gênio exemplificado por Shakespeare não poderia ser encontrado no país vizinho, por conta do refinamento e da espiritualidade típicas desta cultura, excessivamente tributária da conversação, da reflexão e da leitura. Daí fomos até Voltaire, que, no "Discurso sobre a tragédia”, retoma a comparação entre ingleses e franceses em termos similares àqueles de Addison, mas com esta novidade: Voltaire sustenta ser preciso falar do amor, já que, com a importância assumida pelas mulheres no espaço público, o amor se tornou o "tema de todas as conversações". Finalmente, examinamos como Diderot 
critica severamente o rococó, alegando tratar-se de uma pintura desprovida de seriedade e, portanto, incapaz de atingir a elevação exigida pela boa pintura. A fim de situar-se neste plano elevado, é preciso que o pintor pare de se ocupar do "feminino" e dos "pequenos hábitos" do presente, como vinham fazendo, Watteau à frente, os mestres franceses da primeira metade do século XVIII.

Atentando às datas dos textos, podemos conjecturar uma história para nossa questão. O ensaio de Addison, de 1711, registra características estilísticas e sociais da França ligadas à forma bem acabada a que chegara o classicismo da época de Luís XIV. Pouco menos de duas décadas depois, Voltaire retoma a oposição, já presente em Addison, entre espirituosidade, refinamento e falta de ousadia dos franceses, de um lado; e selvageria, sublimidade e ausência de cultura dos ingleses, de outro. Com um acréscimo essencial: bem ao gosto da década de 1730, período em que o rococó atingiu seu maior prestígio junto ao público, Voltaire, reconhecendo o espaço social ocupado pelas mulheres em sua época, toma para si a tarefa de falar do amor - o assunto em torno do qual giram todas as conversações - em suas tragédias. Porém, esse programa de conciliação entre a grandeza trágica e elementos menos elevados, ligados à representação do feminino, é abandonado na década de 1760, quando Diderot aponta que o "assombroso", o "enorme" e o "grandioso" são irredutíveis à representação do feminino emblematizada pela pintura rococó. Se levarmos em conta que o texto de Kant por onde iniciamos data de um ano antes do Salão de 1765, podemos arriscar conjecturar que a posição de Diderot exprime a reação de setores da inteligência francesa diante da efeminação geral da cultura nacional - tendência e reação estando tão acentuados na passagem da primeira à segunda metade do século XVIII, que até mesmo um professor universitário da Prússia oriental atento aos fatos acusou seu registro.

Desnecessário dizer que o apelo enérgico ao elemento "grandioso", "simples" e "rústico" como parte essencial da representação pictórica ou literária e, sobretudo, da reflexão moral setecen- 
tista esteve longe de ser exclusividade de Diderot. Constata-se, a partir da segunda metade do século XVIII, retórica semelhante (embora com ênfases distintas) em outros autores ${ }^{12}$. Recorde-se, a propósito, das afirmações de Rousseau sobre o valor de Esparta diante de Atenas ou dos nativos ameríndios diante dos europeus, assim como a desvalorização da aparência e dos "costumes efeminados", no primeiro Discurso ${ }^{13}$. Em vez de simples idiossincrasia pessoal, essa condenação moral da exterioridade converge com um juízo de época, conforme o qual o apego ao feminino e às noções que sua representação articula (a aparência, o luxo e o Bel esprit) prejudicam a moral e os costumes, tornando mais remota a realização da liberdade humana. Nessa mesma direção, Louis-Sébastien Mercier (1740-1814) beira à ferocidade, quando afirma, no início da década de 1770 :

Designaria de bom grado todos esses pintores que saem atrás de miniaturas de "autores-mulheres"; dão atenção somente ao que é brilhante; não falam senão de lançar faíscas e, sob o pretexto de escrever com espírito, rabiscam palavras que, perfiladas elegantemente, nada significam. (Mercier, 1773 , p. 79 [nota a]).

Na esteira do Salão de 1765 e dos Ensaios sobre a pintura de Diderot, o rococó desempenha para um grupo de intelectuais franceses uma referência importante, representando o mais das vezes o alvo do ataque, por ser visto como um estilo afetado, amaneirado, efeminado e frívolo. "Peinture de boudouir", não pintura

12 Para a análise da "Woman Question" na França setecentista, ver o instigante ensaio de M. Hyde, "Boucher, Boudoir, Salon: Cherchez la Femme" (Hyde, 2006, p. 25-81). 13 "Oh, Fabrício! que teria pensado vossa grande alma, se, voltando à vida, para vossa infelicidade, vísseis a face pomposa dessa Roma salva por vosso braço e que vosso nome respeitável ilustrou mais do que todas as suas conquistas? 'Deuses', teríeis dito, 'em que se transformaram esses tetos de choupanas e esses lares rústicos nos quais outrora habitavam a moderação e a virtude? Que esplendor funesto é esse, que sucedeu à simplicidade romana? Que língua estranha é essa? Que costumes efeminados [moeurs efféminées] são esses?" (Rousseau, 1978, p. 341, grifos nossos). 
séria. Sabemos agora que essa avaliação é uma reação à efeminação da cultura francesa da primeira metade do século XVIII, que também repercutiu fora da França. Kant tira daí as consequências, quando, nas Observações, afirma: "o sublime deve ser sempre grande, o belo pode também ser pequeno. O sublime precisa ser simples, o belo pode ser adornado e amaneirado" (Kant, 2002, A 8). O quadro se completa quando, um pouco adiante, afirma que a mulher é bela, o homem, sublime (Id., ibid., A 47-48).

\section{Conclusão}

O que extrair desse breve percurso? Primeiro, uma constatação: no curso do século XVIII, assiste-se tanto a uma transformação significativa da cultura e dos costumes franceses (aquilo que se classificou à época como "efeminação"), quanto a diferentes reações a seus efeitos, que apontam, todavia, na direção de um recrudescimento. Assim, à tentativa de conciliação entre o feminino e o elevado (Voltaire) segue-se a desaprovação do valor poético do feminino (Diderot), concomitante a formas mais severas e abrangentes - e cada vez mais contundentes - de recusa do espaço social das mulheres e dos efeitos que isso produz sobre os costumes (em certa medida, Rousseau; seguramente, Mercier).

Além disso, nosso percurso lança uma pista a ser seguida em uma outra ocasião. O que foi classificado como "efeminação" exprimiu, não apenas na história da pintura com o rococó, mas no conjunto da cultura francesa da primeira metade do século XVIII, a primeira ruptura com o clássico. A Grande Maneira do século XVII foi substituída pela investigação de outras formas de sensibilidade e vida social, liberadas com as transformações por que passou a sociedade parisiense com a morte de Luís XIV e a Regência ${ }^{14}$. Já a reação à "efeminação", iniciada a partir da metade do 
século XVIII e da qual, como vimos, participou Diderot, almejou não tanto suprimir o espaço social adquirido então pelas mulheres (o que seria essa utopia?), quanto, mais concretamente, impedir que os valores poéticos e morais fossem inteiramente assimilados à representação em voga do feminino. A reação poética contra o excesso de efeminação foi, tudo somado, uma reivindicação da moral contra os costumes - esses, sim, o foco do questionamento em causa.

A evolução desse processo na Inglaterra é instrutiva pelo contraste. Ao contrário de Addison, Hume não aprovará completamente Shakespeare e exprimirá reticências às "atrocidades" do teatro britânico (alinhando-se ao juízo conciliador de Voltaire, que examinamos anteriormente):

Uma ação representada na tragédia pode ser muito sangrenta e atroz. Pode suscitar movimentos de horror tais que não se deixam suavizar em prazer, e a maior energia de expressão empregada em descrições dessa natureza só serve para aumentar nosso mal-estar. Assim é a ação representada na Madrasta ambiciosa [de N. Rowe], na qual um venerável idoso, no ápice da fúria e do desespero, se atira contra uma coluna e, ao bater a cabeça contra ela, mancha-a inteira com miolos misturados a jorros de sangue. O teatro inglês é superabundante em imagens chocantes como esta. (Hume, 2011, p. 170-171). ${ }^{15}$

Seria Hume, além de cético, francófilo? Nem é preciso ir tão longe. Como se sabe, Hume fez da formação do gosto e do refinamento o núcleo de sua paidea. E isso aponta para uma orientação

15 Num ensaio anterior, de 1742, Hume, talvez tendo em mente o prefácio de Voltaire ao Brutus, tocava diretamente no ponto discutido por nós: "Os ingleses se aperceberam da escandalosa licenciosidade de seu teatro pelo exemplo da decência e moral francesa. Os franceses estão convencidos de que seu teatro se tornou efeminado pelo excesso de amor e galanteio, e começam a aprovar o gosto mais másculo de algumas nações vizinhas" "Do surgimento e progresso das artes e ciências", in Hume, 2011, p. 92). 
que contrasta claramente com as objeções de certa inteligência parisiense da segunda metade do século XVIII contra os costumes na França, já que, no caso de Hume, não há como dissociar a moral dos costumes. Atesta-o esse passo sobre o método utilizado na Investigação sobre os princípios da moral:

A própria natureza da linguagem guia-nos quase infalivelmente na formação de um juízo dessa espécie [ie, relativo aos valores sobre o mérito pessoal]; e assim como qualquer língua possui um conjunto de palavras que são tomadas em um bom sentido e outras em um sentido oposto, basta a mínima familiaridade com o idioma para nos orientar, sem nenhum raciocínio, na coleta e arranjo das qualidades que são estimáveis ou censuráveis nos homens. (Id., 2003, p. 231).

Por mais que seja atravessada pelo "luxo" e pelo "ornamento" (conceitos tradicionalmente ligados ao feminino), a prática social e linguística cotidiana permanece, aos olhos de Hume, a base dos juízos sobre a virtude: a investigação moral não poderia ignorá-la, sob o risco de tornar-se abstrata e dogmática ${ }^{16}$. Poderíamos indagar se a opção de Hume é apenas metodológica ou conjecturar se o recurso a um método que se apoia abertamente sobre a língua e as práticas cotidianas já não decorre de uma aceitação dos costumes e dos valores em circulação. A conjectura sendo válida, poderíamos então ser tentados a investigar se Hume era mais simpático ao

16 Em ensaio datado de 1742, "Dos preconceitos morais", Hume critica a mania filosófica que, sob o pretexto de "reformar preconceitos e erros, ataca todos os mais afetuosos sentimentos do coração e as mais úteis propensões e instintos que podem governar uma criatura humana". A "refinada busca de felicidade ou de perfeição", conclui-se daí, não deveria nos fazer distanciar "em demasia das máximas aceites de conduta e comportamento" - entenda-se, dos costumes vigentes ( "Dos preconceitos morais", in Hume, 2011, p. 227 e 229). Para a visão antípoda: "o princípio da obrigação não se há de buscar aqui na natureza do homem ou nas circunstâncias do mundo em que o homem está posto, mas sim a priori exclusivamente nos conceitos da razão pura, e [...] qualquer outro preceito baseado em princípios da simples experiência, e mesmo um preceito em certa medida universal, se ele se apoiar em princípios empíricos, num mínimo que seja, talvez apenas por um só móbil, poderá chamar-se na verdade uma regra prática, mas nunca uma lei moral" (Kant, 1980, p. 104). 
"feminino" do que alguns de seus amigos philosophes; ou até mesmo se a Londres setecentista não seria menos "feminina" que Paris... Uma via mais promissora que essa, menos psicológica e mais "materialista", é indicada por Kant de modo indireto, quando diz que a razão pela qual a língua francesa se tornou "a língua universal da conversação, principalmente do mundo feminino refinado", enquanto a inglesa se tornou "a língua comercial mais difundida no mundo dos negócios" se deve, tudo somado, à "diferença entre a situação continental e a situação insular" (Kant, 2006, p. 207 [AA: VII: 312]). Arrisquemo-nos a traduzir essa diferença (na qual, convém notar, Kant alinha sua Prússia, também "continental”, ao lado da França): enquanto os ingleses em boa medida já constituíam sociedade burguesa desde o início do século XVIII, os franceses permaneceram às voltas com a herança do absolutismo até, pelo menos, 1789. Nisto talvez resida a explicação para que a geração de 1750 da qual fez parte Diderot tenha se permitido negligenciar a primeira ruptura com o clássico, consumada com a Regência. Watteau e o rococó, afinal, deram expressão a uma modernidade ainda não burguesa, ao menos não no sentido que seria buscado pela retórica pré-revolucionária que começou a se formar a partir da segunda metade do século XVIII entre os philosophes.

Em todo caso, fato é que, na França, a reação ao "feminino" foi um dos fatores que engendraram a diferenciação entre ideal prático e o âmbito dos costumes - o que, a ver mais de perto, foi a condição para a produção de um ideal moral exterior ao que se detectou como efeminação da cultura ou civilização modernas $^{17}$. Embora trouxesse consigo a ruptura com a virilidade e

17 Pedro P. Pimenta toca nesta questão ao examinar os significados ligados à aparição do termo "civilização" na França e na Inglaterra setecentista. Conforme E. Benveniste, retomado por Pimenta, "civilização" (civilisation) aparece primeiramente em Mirabeau (Traité de populations, 1757), e - em direta relação com o processo que estamos discutindo - designa "o abrandamento dos costumes, a urbanidade, a polidez, e os conhecimentos, distribuídos de maneira que seus benefícios sejam sentidos" (apud Pimenta, 2013, p. 123). Pimenta observa (Id., ibid., p. 126) que, embora Hume não use o substantivo, mas só sua forma adjetivada (civilized), ele fala, em todo caso, 
grandiosidade do ideário clássico, a modernidade acarretada pela "efeminação" (e da qual o rococó foi uma expressão bem acabada) pareceu pouca coisa aos olhos de quem ainda tinha uma revolução pela frente - o que, pensando bem, é compreensível. À modernidade concebida como "efeminação" (próxima ao processo reconstruído por N. Elias) forjou-se então, através da recusa poética e moral do feminino, a invenção da modernidade como autonomia. Só que isso, curiosamente, significou, sob um ponto de vista decisivo, reatar com o clássico, já que a autonomia se viu apresentada como um equivalente da elevação poética e moral enaltecida pela Grande Maneira. É o que fica claro na história da pintura francesa de todo o período, que revela haver muito em comum entre a composição de Le Brun, Greuze e David. Quem realmente destoa disso é Watteau.

Será ir longe demais? Como sugere a leitura de Rousseau, e não de todo longe dele, de Kant, a ideia de liberdade como autonomia em vias de formação se tingiu de traços elevados e viris, em franca reação diante da efeminação da qual a sociedade francesa foi tomada como o exemplo mais acabado durante o século XVIII. A história não finda aí. Frustradas as expectativas morais abertas pela revolução, a inteligência francesa do século XIX não demoraria a redescobrir não apenas Watteau, como também o valor poético e moral do ornamento e da aparência, associados ao feminino. Atestam-no essas linhas de Baudelaire, que admitem ser lidas como resposta ao pouco caso que Diderot fizera da representação de nossos pequenos hábitos (e que ressoa na afirmação de Kant de que "a maquiagem é engano" [Kant, 2006, p. 49 [AA: VII: 150]]): "Qual poeta ousaria, na pintura do prazer causado pela aparição de uma beleza, separar a mulher de sua indumentária?” (Baudelaire, 1980, p. 809).

de "civility or good manners" por oposição à "ferocidade" (ferocity) - que, por nossa conta, aproximaríamos do "viril" elisabetano. 


\section{Referências bibliográficas}

ADDISON, J. The Spectator [set. 1711]. Edição on-line disponível no projeto Gutenberg: http://www.gutenberg.org. Consultado em 17 de julho de 2014 .

BAUDELAIRE, C. "Le peintre de la vie moderne". In: Euvres complètes. Paris: Robert Laffont, 1980.

CHAVANNE, B. "Quand la peinture se fait entendre". In: Le Théâtre des passions (1697-1759). Lyon: Fage Editions, 2011.

DIDEROT, D. Obras escolhidas: Estética, Poética e Contos. Trad. Jacó Guinsburg. São Paulo: Perspectiva, 2000.

. Euvres, IV: Esthétique-Théâtre. Éd. L. Versini. Paris: Robert Laffont, 1996.

FRANTZ, P. \& MARCHAND, S. (Org.). Le Théâtre français du XVIII ème siècle. Paris: L'avant-scène théâtre, 2009.

HAUSER, A. História social da arte e da literatura. Trad. Álvaro Cabral. São Paulo: Martins Fontes, 1998.

HUME, D. A arte de escrever ensaio. Tradução Márcio Suzuki; Pedro Paulo Pimenta. São Paulo: Iluminuras, 2011. Investigações sobre o entendimento humano e sobre os princípios da moral. Trad. José Oscar Marques. São Paulo: Ed. Unesp, 2003.

HYDE, M. Making Up the Rococo - François Boucher and his Critics. Los Angeles: Getty Publications, 2006.

KANT, I. Antropologia de um ponto de vista pragmático. Trad: Clélia Martins. São Paulo: Iluminuras, 2006. . Observações sobre o sentimento do belo e do sublime. Trad. Vinícius de Figueiredo. Campinas: Papirus, 2002. . "Fundamentação da Metafísica dos costumes". Trad. Paulo Quintela. In: Kant, v. II. São Paulo: Abril Cultural, 1980 (Col. Os Pensadores).

LEVEY, M. Du Rococo à la Révolution [1966]. Paris: Thames \& Hudson, 1989 .

MERCIER, L.-S. Du Théâtre, ou Nouvel essai sur l'art drama- 
tique. Amsterdã: E. van Harrevelt, 1773.

PIMENTA, P. P. A imaginação crítica: Hume no século das Luzes.

Rio de Janeiro: Beco do Azougue, 2013.

ROUSSEAU, J.-J. "Discurso sobre as ciências e as artes". Trad. Lourival Machado. In: Rousseau. São Paulo: Abril Cultural, 1978 (Col. Os Pensadores).

VOLTAIRE. Dictionnaire philosophique. Paris: Garnier-Flammarion, 1964 .

. Euvres complètes - Théâtre I. Paris: Baudouin Frères, 1828.

\section{Ilustrações}

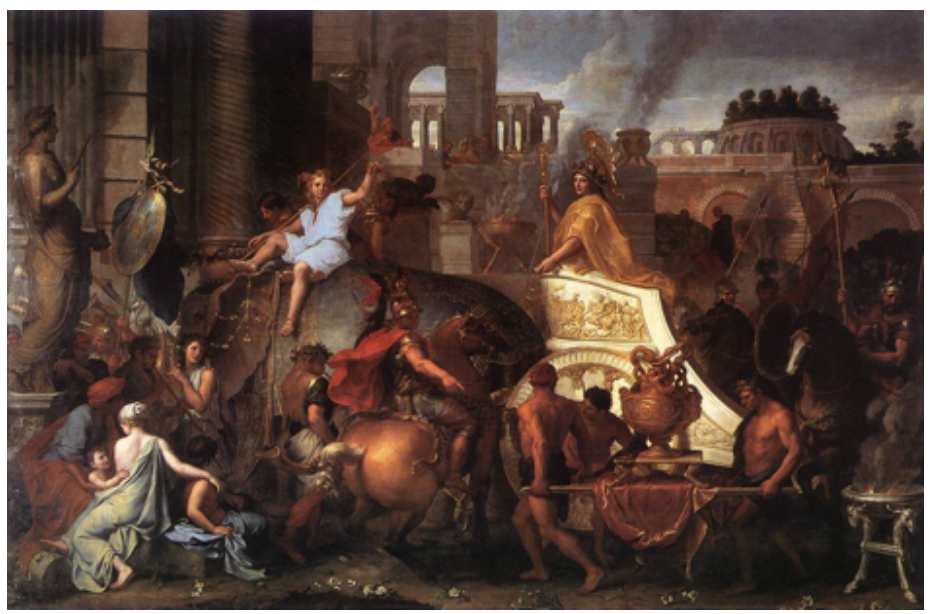

Ilustração 1: Charles Le Brun (1619-169o), L'entrée de Alexandre Le Grand dans Babylone (c. 1664-65). Óleo sobre tela, Musée du Louvre, Paris. 


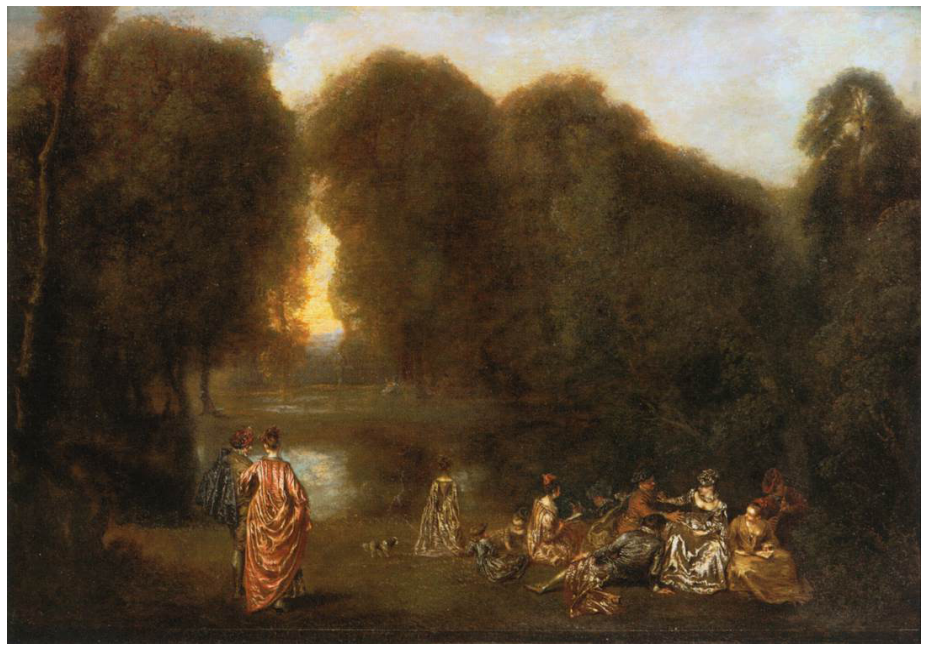

Ilustração 2: A. Watteau. L’assemblée dans un parc (1717). Óleo sobre tela. $32 \times 46 \mathrm{~cm}$. Musée du Louvre, Paris.

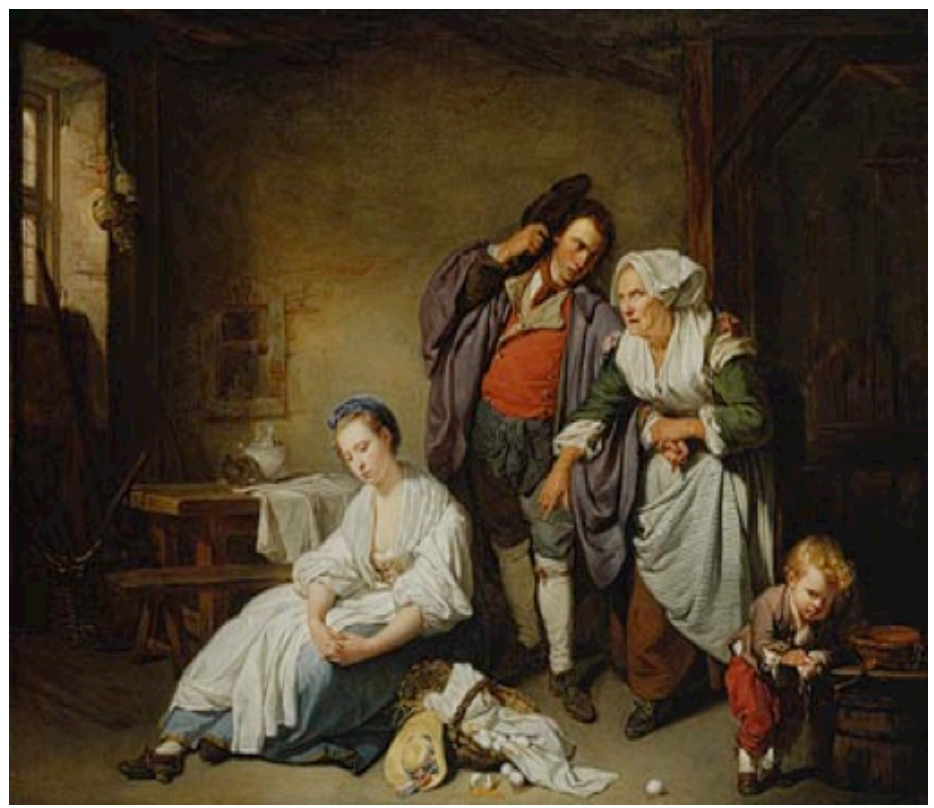

Ilustração 3: J.-B. Greuze (1725-1805), Les oeufs cassés (1756). Óleo sobre tela. The Metropolitan Museum of Art, Nova York. 